\title{
Analysis of politeness strategies in Japanese and Korean conversations between males
}

Focusing on speech levels and speech level shifts

\author{
Eun Mi Lee \\ Myongji University, Korea
}

This study analyzed the uses and functions of speech levels and speech level shifts in natural conversations between two unacquainted males. Similarities and differences between Japanese and Korean languages have been investigated. For the Japanese language, speech levels do not clearly reflect the hierarchical relationships based on the interlocutors' age by utilizing "non-marked utterance (NM)" This finding implies that modern Japanese people tend to avoid the use of honorifics which clearly indicates the hierarchical relationships between speakers at the sentence level. On the other hand, speech level shifts reflect hierarchical relationships between speakers, which means that Japanese seem to conform to normative language use at the discourse level. For the Korean language, both speech levels and speech level shifts clearly reflect the hierarchical relationships based on the interlocutors' age. This result suggests that Korean have a strong tendency to preserve the normative honorific usage of polite forms according to age difference both at the sentence level and at the discourse level. These results suggest that speech levels, considered to be socio-pragmatically obligatory, have a strategic-use aspect for both languages, including the use of "non-marked utterances" and that of downshifts. It was also discovered that Japanese tend to use speech levels more strategically than Korean. Consequently, Japanese uses honorifics strategically in order to evade hierarchical relationships based on age, whereas Koreans tend to conform to social norms that derive from tenets of Confucianism, a philosophy emphasizing politeness toward older people; such practice encourages younger people to use polite forms to their elders.

Keywords: Japanese, Korean, conversations between males, speech levels, speech level shifts, politeness strategy, discourse politeness 


\section{Introduction}

Both Japanese and Korean are known as languages with complicated honorific systems; there has been extensive research on each language, and moreover, comparative and contrastive studies on the honorifics of both languages have been conducted (e.g., Ikuta 1983; Umeda 1990; Ogino et al. 1990, 1991; Yu 1996; Ikeda 2000; Usami \& Lee 2003; Ijūin 2004; Takiura 2005; Han 2007; Han \& Umeda 2009; Lee 2008; Shin 2009; Hong 2010). Since language is like a living organism and reflects the historical, cultural, and social situation of the society where the language is spoken, Japanese and Korean are predicted to show different linguistic behaviors despite having similar honorific systems. In such honorific systems, a verb has several forms, such as polite and non-polite forms. Also, the degree of politeness in a sentence, which is mainly determined by the choice of verb form, is defined as the speech level. The choice of a verb form depends on the speaker's attitude toward the person that he/she is addressing as well as on the speaker's attitude toward the subject of expression (Martin 1964). So far, previous research on the honorific system has primarily focused on the speech levels in the viewpoint of the usage of politeness markers such as respectful and humble forms (e.g., Han 2007; Kim 2009). In addition, although politeness is generally considered to be a linguistic behavior intended to maintain smooth communications, most research on politeness has mainly focused on honorifics, which is a linguistic form, in both countries. Moreover, some researchers have claimed that there is little room for any rational or voluntary strategy in languages like Japanese, where the use of honorifics is socio-pragmatically obligatory (e.g., Matsumoto 1988; Ide 1989; Ide \& Yoshida 1999). That is, the choice of linguistic form is generally restricted due to the honorific system in both languages.

On the other hand, there have been recent studies on honorifics, from the viewpoint of politeness in each language (e.g., Ijūin 2004; Takiura 2005; Lee 2008; Saito 2010). Lee (2008) and Saito (2010), for instance, have revealed that inferiors use the non-polite forms as well as the polite forms to their superiors when hierarchical relationships are manifested. In addition, in actual conversations, it can be frequently observed that the use of non-polite form makes an addressee feel comfortable, whereas the use of the polite form makes the addressee feel uncomfortable. This implies that honorifics can often be used strategically. However, few comprehensive analyses, including conventional language forms and individual strategies, have examined the overall contexts of the conversation and the intention of the speaker.

Since the honorific systems in both languages restrict the choice of linguistic form, individual strategy becomes limited within a sentence. According to Usami (2002), individual strategy is reflected much more in the unrestricted factors of 
discourse, such as speech level shifts ${ }^{1}$ and the frequency of topic initiation, than in the speech levels of a sentence. Therefore for a more comprehensive analysis of a speaker's intention, the discourse level including sentence level needs to be considered. Based on these backgrounds, the concept of discourse politeness ${ }^{2}$ was proposed by Usami (e.g., 2001b, 2002), and a number of studies have pursued various interests in pragmatics from the perspective of discourse politeness (Olivieri 1999; Otsuka 2004; Kiyama 2005; Terkourafi 2005; Xie 2007; Chang \& Haugh 2011; Kádár 2012; Chung 2014).

On the other hand, it is generally recognized that within contemporary Japanese and Korean society, age and social status are considered to constitute a type of power variable. Many empirical studies have reported that an addressee's age and social status are reflected in many aspects of language use (e.g., Ogino 1986; Minami 1987; Kubota 1990). Therefore, the present study focused on age as the target social-cultural variable, controlling the other factors that might play a role in how politeness is reflected in actual language use by drawing from Brown and Levinson's (1987) formula in which the "weightiness of an FTA (face-threatening act)" is the sum of D (social distance between speaker and hearer), P (relative power between speaker and hearer), and $\mathrm{R}$ (absolute ranking of imposition in the particular culture). Consequently, when D and $\mathrm{R}$ are controlled as constants, age may be the most influential factor of linguistic behavior.

In the present study, a comparative analysis on honorifics in the languages of Japanese and Korean was conducted by taking a pragmatic viewpoint of politeness by using data from natural conversations collected under controlled conditions. Specifically, the uses and functions of speech levels and speech level shifts were revealed by analyzing the effects of age on language use through the theoretical lens discourse politeness.

1. Speech level shifts is defined as the speaker's shifts in his or her sentence-final speech levels such as [desu / masu] and [hayo / hapnita] to non-polite ones such as [da /dearu] and [hay / hanta], or from non-polite forms to polite ones (Lee, E.M. 2008).

2. "Discourse Politeness" is defined as "the functional dynamic whole of factors of both linguistic forms and discourse-level phenomena that play a part in the pragmatic politeness of a discourse" (Usami 2006). 


\section{Method}

\subsection{Subjects}

To analyze how a speaker (who will be referred to as a "base") manipulates language use according to the "power relationships" underlying the age differences of interlocutors, D (social distance) and R (ranking of imposition) were controlled, while only age was designed to be a variable. Therefore, subjects were recruited primarily by their age. The base subjects included 35-year-old male university graduates with social experience since educated adults of this age are generally considered able to manipulate the use of honorifics (Minami 1987). I assigned 35-year-old males as bases, 45-year-old subjects as older interlocutors, 35-year-old subjects as same-age interlocutors, and 25-year-old subjects as younger interlocutors. The reason for the 10 year age difference was to allow for an easy recognition of age difference by appearance. The design of data collection is owed to the Usami's previous study (2002).

As shown in Table 1, a base subject was asked to participate in conversations with six different both male and female interlocutors that were "older," "same age," and "younger". Furthermore, in order to keep subjects' social distance constant, the base subjects were asked to converse with an unacquainted person. In total, data from 60 conversations were collected from 10 bases comprised of five males for each language.

Table 1. Combination of pairings for a base subject

\begin{tabular}{lllll}
\hline Language & $\begin{array}{l}\text { Base } \\
\text { subjects }\end{array}$ & Interlocutors & $\begin{array}{l}\text { No. of } \\
\text { conversations }\end{array}$ \\
\hline Japanese & Five & Older Female (OF, age:45) & Older Male (OM, age:45) & 30 \\
& $\begin{array}{l}\text { Base Males } \\
\text { KM, age:35) }\end{array}$ & Same-age Female (SF, age:35) & Same-age Male (SM, age:35) & \\
& $(\mathrm{BM}$ Younger Female (YF, age:25) & Younger Male (YM, age:25) & 30 \\
Korean & Five & Older Female (OF, age:45) & Older Male (OM, age:45) & 30 \\
& Base Males & Same-age Male (SF, age:35) & Same-age Male (SM, age:35) \\
& $(\mathrm{BM}$, age:35) & Younger Female (YF, age:25) & Younger Male (YM, age:25) \\
\hline
\end{tabular}

\subsection{Procedure}

In the absence of the researcher, each base conversed with six different people for approximately 15 minutes each. Conversation topics were not provided, and the subjects were instructed to converse naturally. Each of the 60 Japanese and Korean dyadic conversations was audio recorded by tape recorders with a microphone 
(Sony TCS-60, Japan) in a room at a university either in Seoul or in Tokyo. The subjects sat facing each other with a table between them. A follow-up 5-step evaluation questionnaire was conducted after each conversation in order to confirm the validity of each conversation by investigating the perception of the speaker's age, awareness of the fact that the conversation was being recorded, and whether the conversation was carried out naturally, and so on.

\subsection{Transcription}

The 60 conversations were transcribed by means of the "Basic Transcription System for Japanese: BTSJ" (Usami 2003) and "BTSK" (Usami et al. 2007). The BTSJ owes many of its advantages to the Child Language Data Exchange System (CHILDES), for its way of representing overlap and inserting context notes for the needs of the researchers (Usami 2002). However, the BTSJ is restricted and designed to transcribe Japanese adult conversations, in which one observes many longer, complex sentences, and much overlapping and insertions of an utterance into the other speaker's grammatical sentence. The BTSK is the Korean version of the BTSJ. Drawing from the procedure outlined in Bakeman and Gottman (1986), the reliability of transcript was conducted as follows. A second trained coder segmented $10 \%$ of the whole transcript ( 3 conversations for each language) and achieved an inter-rater agreement of 0.875 in Japanese and 0.851 in Korean, using Cohen's kappa. The resulting agreement rates are satisfactory, as an agreement over $70 \%$ (0.7) in the Kappa test is considered high.

\subsection{Coding}

The transcribed data were coded according to the items of analysis. Each utterance ${ }^{3}$ is regarded as a unit of analysis, and all utterances were coded based on "speech levels" at the sentence level, and subsequently, on "speech level shifts" at the discourse level, according to Usami (2002).

3. Utterance is a unit of analysis for "readability" and "quantitative analysis" of natural conversation. In other words, utterance is a structurally complete sentence, but interaction such as turn-taking and pause in conversations are considered to judge an incomplete sentence whether it is utterance or not (Usami, 2003). 


\subsubsection{Speech levels}

All utterances were coded in two ways: sentence-final speech levels and speech levels in total utterances.

\section{Sentence-final speech levels}

Generally, it is considered that the respect or deference of a speaker to an addressee is most clearly represented at the sentence-final speech levels both in Japanese and Korean (e.g., Oishi 1983; Kikuchi 1994; Ikeda 2000; Usami 2002). Sentence-final speech levels are closely related to the addressee-honorifics and represent the speaker-addressee relationship. Most previous studies on sentence-final speech levels have focused on the use of linguistic politeness markers, and sentence-final speech levels have been classified into two categories, "polite forms" and "non-polite forms". In this study, however, the use of speech levels was explored collectively by including an additional category, "non-marked utterances" to indicate an utterance without politeness markers. Therefore, sentence-final speech levels were classified into the following three categories.

P (Polite forms):

"desu (copula)/masu (verbal suffix)" forms in Japanese, "immida, yo (copula)/ hammida, hayyo (verbal suffix)" in Korean and their derivatives

$\mathrm{N}$ (Non-polite forms):

Plain or dictionary forms and their inflected forms

NM (Non-marked utterances):

Utterances that include no sentence-final linguistic markers of the politenes level. Most incomplete utterances such as "onamaewa '(what's) your name' ...?" were classified into this category.

\section{Speech levels in the whole utterance ${ }^{4}$}

The speech levels in an utterance included respectful and humble forms to determine speech levels in the whole utterance while only linguistic forms at the sentence-final were considered to determine sentence-final speech levels. In this study, speech levels in total utterances were classified into the following four categories by evaluating the highest-degree of politeness level of linguistic forms.

4. In the sentence-final speech level mentioned above, the respect or deference of a speaker to an addressee was observed. "Speech levels in the whole utterance" in this study is the category devised to observe other linguistic forms in the sentence when sentence-final speech level is NM. 


\section{S (Super-polite forms): ${ }^{5}$}

In Japanese, utterances that include respectful or humble forms, ${ }^{6}$ as well as respectful prefixes such as " $\mathrm{o} / \mathrm{go}$ ". In Korean, utterances that include respectful or humble forms, as well as the honorific infix "usi/si".

\section{P (Polite forms):}

Utterances that include the polite forms

$\mathrm{N}$ (Non-polite forms):

Utterances that include the non-polite forms

\section{NM (Non-marked utterances):}

Utterances that include no linguistic markers of politeness

Table 2 shows how the Japanese and Korean equivalents of 'he/she goes' would be coded depending on their politeness markers.

As shown in Table 2, both forms (1) and (3) have the verbal suffix masu for Japanese and mmida for Korean, both of which are markers of the polite forms (P). However, the respectful verb irassharu 'go' for Japanese and gasida 'go' for Korean are used in (1), whereas the normal verb iku 'go' for Japanese and gada 'go' for Korean are used in (3). Therefore, form (1) in Japanese and Korean was coded as the polite forms $(\mathrm{P})$ at the "sentence-final speech levels", while super-polite forms (S) were coded at the "speech levels in the whole utterance". However, form (3) in Japanese and Korean was coded as the polite forms (P) at both levels.

5. Since referent honorifics refers to respectful or humble forms, S (Super-polite forms) I designated in this study means referent honorifics. In this study, since I analyzed how a speaker (base subject) manipulates language use according to the interlocutors' age, I analyzed the referent honorifics related with the interlocutor and interlocutor's territory. Therefore, the referent honorifics not related with interlocutor, 5 and 11 out of total Japanese and Korean conversations respectively, were excluded in this analysis.

6. In the Japanese language, respectful forms are made regularly by placing o/go as a prefix and ni naru at the end of the conjugated form of a verb. For example, omochininaru is the respectful form of motsu to 'carry'. Humble forms are made regularly by placing the prefix o/go and suru at the end of the conjugated form of a verb. For example, omochisuru is the humble form of motsu 'carry'. In addition to regularly formed respectful and humble verb expressions, there are a few verbs that have a specific respectful verb or a humble verb, respectively, such as ossharu, the respectful verb of iu 'say' and itasu, the humble verb of suru 'do'. In Korean, except for boepda, for the humble verb of boda 'see', there is no humble form. The Korean language makes its respectful forms regularly with the honorific infix usi/si. There are a only few verbs that have a respectful verb such as jumusida, which is the respectful verb of jada 'sleep', and gyesida, the respectful verb of issda 'stay'. 
Table 2. An example of the coding of speech levels for "he(she) goes" in English

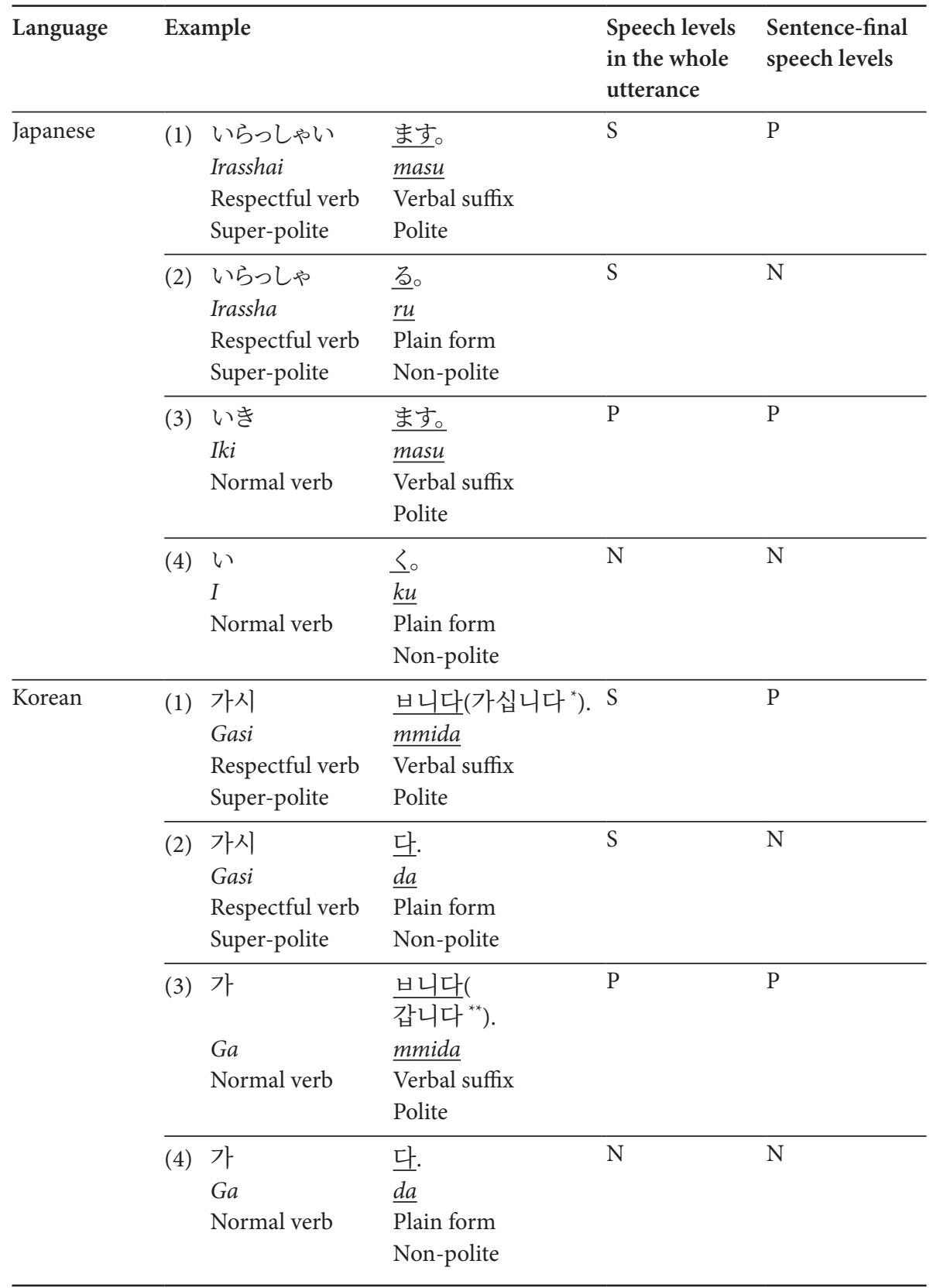

* '가십니다' is a combined form of '가시' and '브니다'.

** '갑니다' is a combined form of '가' and '비니다'. 
On the other hand, the ends of both forms (2) and (4) have plain forms classified as non-polite forms without the polite verbal suffix masu for Japanese and mmida for Korean. The respectful verb irassharu 'go' for Japanese and gasida 'go' for Korean are used in (2), whereas the normal verb iku 'go' for Japanese and gada 'go' for Korean are used in (4). Therefore, form (2) in Japanese and Korean was coded as the non-polite forms $(\mathrm{N})$ at the "sentence-final speech levels" while it was coded as the super-polite forms (S) at the "speech levels in the whole utterance". Yet, form (4) in Japanese and Korean was coded as the non-polite forms (N) at both levels.

\subsubsection{Speech level shifts}

\section{Speech level shifts}

In this study, a speech level shift is defined as the speaker's shift in his or her sentence-final speech level as mentioned in footnote 1 . The shift from the polite forms $(\mathrm{P})$ to the non-polite forms $(\mathrm{N})$ was coded as "downshift," and the shift from the non-polite forms (N) to the polite forms (P) was coded as "upshift". When a sentence-final speech level had already been shifted once and maintained its form for the next several utterances, it was coded as "no-shift".

D : Downshift

$\mathrm{U}:$ Upshift

$\mathrm{N}$ : No-shift

\section{Politeness effects of speech level shifts}

According to "discourse politeness", politeness effects arise from the movement of linguistic behaviors, a deviation from the default (unmarked behaviors) of a discourse; they are classified into three categories as shown below.

PP (Plus politeness effects):

An effect that is pleasant, comfortable, or polite

NP (Neutral politeness effects):

An effect that is neither particularly polite nor unpleasant, such as emphasis or topic switching

MP (Minus politeness effects):

An effect that is unpleasant or rude

In this study, the politeness effects caused by downshifts were coded. Examples of the actual coding in Japanese are presented in Table 3. This conversation describes a scene in which a younger base JBM1 answers the question "Nanka supo-tsu nasattemasuka 'Do you enjoy any sports'?” by an older interlocutor JOF4. In No. 85, 
JOF4 uses the most polite expression including both the super-polite form respectful "nasaru 'do" in the middle of the sentence and the polite form "masu (verbal suffix)" at the end of the sentence in order to ask "Nanka supo-tsu nasattemasuka 'Do you enjoy any sports?'” In No. 86, however, JBM1 uses the non-polite form "nande 'because' (conjunctive particle)" to express "dame 'I am not (very sporty)." JMB1's utterance of "dame nande 'not being (very sporty)" downshifts with a laugh from JOF4's polite form, and the intention of this is to create a good feeling to reduce the psychological distance with JOF4. In response to No. 86, JOF4 in No.88 is advising JBM1 to swim for exercise with friendly voice, which could be attributed to the friendly mood JBM1 made though advising something to interlocutor is not usual in the first-meeting conversation. According to the discourse politeness theory, the downshift in No. 86 creates a comfortable mood, thereby introducing a plus politeness effect.

Table 3. An example of an actual coding of a conversation in Japanese (see transcription conventions in Appendix)

\begin{tabular}{lllll}
\hline No. Speaker Contents of utterance & $\begin{array}{l}\text { Speech } \\
\text { levels in fentence- } \\
\text { the whole levels } \\
\text { utterance }\end{array}$ & $\begin{array}{l}\text { Speech Politeness } \\
\text { level effects } \\
\text { shifts }\end{array}$ & \\
& & & \\
\hline
\end{tabular}

\begin{tabular}{|c|c|c|c|c|c|c|}
\hline 85 & $\mathrm{JOF}_{4}^{*}$ & $\begin{array}{l}\text { 何かスポーツなさってますか?。 } \\
\text { Nanka supo-tsu nasatte masu ka? } \\
\text { 'Do you enjoy any sports?' }\end{array}$ & S & $\mathrm{P}$ & & \\
\hline $86-1$ & JBM1 & $\begin{array}{l}\text { いえー、僕はもう全然もう一,", } \\
\text { Ie-, boku wa mō zenzen mō-,, } \\
\text { 'No.None at all,,', }\end{array}$ & & & & \\
\hline 87 & JOF4 & $\begin{array}{l}\text { そうですか。 } \\
\text { Sō desu ka. } \\
\text { 'Really?' }\end{array}$ & $\mathrm{P}$ & $\mathrm{P}$ & & \\
\hline $86-2^{* *}$ & JBM1 & $\begin{array}{l}\text { だめなんで<笑い>。 } \\
\text { Dame nan de<warai }>\text {. } \\
\text { 'Because I am not very sporty. } \\
<\text { laughter>’ }\end{array}$ & $\mathrm{N}$ & $\mathrm{N}$ & $\mathrm{D}$ & PP \\
\hline 88 & JOF4 & $\begin{array}{l}\text { 健康のためにぜひ泳ぎください。 } \\
\text { Kenkō no tame ni zehi oyogi } \\
\text { kudasai\}. } \\
\text { 'You should certainly do some } \\
\text { swimming, if only for your } \\
\text { health. }\end{array}$ & $\mathrm{P}$ & $\mathrm{P}$ & $\mathrm{U}$ & \\
\hline
\end{tabular}

\footnotetext{
${ }^{\star} \mathrm{J}, \mathrm{K}, \mathrm{F}$, and M represent Japanese, Korean, female, and male, respectively. B, O, S, and Y represent base, older, same-age, and younger, respectively.

${ }^{* *}$ Line $86-1$ and $86-2$ consist of one utterance so they were coded only once (86-2). Since JOF4 broke in the utterance of JBM1 by saying "Sō desu ka 'Really?'”, the utterance was separated into two lines according to transcription rule.
} 


\subsubsection{Coding reliability}

Following the procedures of Bakeman and Gottman (1986), a second trained coder coded a random sample of $10 \%$ of all transcripts to ensure reliability. The proportion of agreements observed (Po) and Cohen's kappa $(k)$ are shown below.

Speech levels

\begin{tabular}{|c|c|c|c|c|}
\hline \multirow[t]{2}{*}{ (1) } & Sentence-final speech levels & $\mathrm{Po}=0.954$ & $k=0.923$ & (Japanese) \\
\hline & & $\mathrm{Po}=0.960$ & $k=0.933$ & (Korean) \\
\hline \multirow[t]{2}{*}{ (2) } & Speech levels in the whole utterance & $\mathrm{Po}=0.921$ & $k=0.867$ & (Japanese) \\
\hline & & $\mathrm{Po}=0.935$ & $k=0.905$ & (Korean) \\
\hline
\end{tabular}

Speech level shifts

\begin{tabular}{|c|c|c|c|c|}
\hline \multirow[t]{2}{*}{ (1) } & Speech-level shifts & $\mathrm{Po}=1.000$ & $k=1.000$ & (Japanese) \\
\hline & & $\mathrm{Po}=1.000$ & $k=1.000$ & (Korean) \\
\hline \multirow[t]{2}{*}{ (2) } & Politeness effect of speech level shifts & $\mathrm{Po}=0.918$ & $k=0.853$ & (Japanese) \\
\hline & & $\mathrm{Po}=0.925$ & $k=0.875$ & (Korean) \\
\hline
\end{tabular}

The categories based on linguistic forms, such as polite forms and non-polite forms, obtained higher values on Cohen's kappa than those that rely on the coder's judgment. These results, however, show very high reliability, as an agreement over $70 \%$ (0.7) in the Kappa test is considered high overall. In addition, since speech level shifts were automatically coded according to the previously coded sentence-final speech levels, the proportions of the agreements turned out to be 1.00 for both Korean and Japanese.

\subsection{Statistical analysis}

The uses and functions of speech levels and speech level shifts were analyzed quantitatively. A two-way analysis of variance (ANOVA) was also conducted to examine if there are statistically significant differences in age groups based on the mean percentage of each speech level and speech level shift.

\section{Results and discussion}

\subsection{Speech levels}

\subsubsection{Sentence-final speech levels}

Table 4 shows the average percentage of "sentence-final speech levels" for Japanese and Korean. For Japanese, the percentage of polite forms (P) is highest followed by that of non-marked utterances (NM), then that of non-polite forms (N). For Korean, the percentage of polite forms $(\mathrm{P})$ is highest followed by that of non-polite forms $(\mathrm{N})$, then that of non-marked utterances (NM). From the viewpoint of discourse 
politeness, it can be understood that the unmarked speech level in conversations between persons who meet for the first time is the polite forms $(\mathrm{P})$. This form is expected because Japanese and Korean people tend to use honorific expressions with each other particularly in situations where they have not yet been acquainted. The percentage of polite forms $(\mathrm{P})$ and non-polite forms $(\mathrm{N})$ in Korean is higher than that in Japanese. Also, an opposite tendency is exhibited between the two languages for the percentage of non-marked utterances (NM).

Table 4. Frequency and percentage of sentence-final speech levels in Japanese and Korean

\begin{tabular}{|c|c|c|c|c|c|c|c|}
\hline \multirow[t]{2}{*}{ Language } & \multicolumn{2}{|c|}{ Polite forms (P) } & \multicolumn{2}{|c|}{ Non-polite forms $(\mathrm{N})$} & \multicolumn{2}{|c|}{ Non-marked (NM) } & \multirow{2}{*}{$\begin{array}{l}\text { Total No. of } \\
\text { utterances }\end{array}$} \\
\hline & No. & Percent (\%) & No. & Percent (\%) & No. & Percent (\%) & \\
\hline Japanese & 1,234 & 63.2 & 252 & 12.9 & 465 & 23.8 & 1,951 \\
\hline Korean & 1,814 & 72.1 & 376 & 14.9 & 326 & 13.0 & 2,516 \\
\hline
\end{tabular}

* The utterances of the base subjects were analyzed to better understand how language can be manipulated to establish a "power relationship" given differences in the age of an interlocutor. Accordingly, the numbers in "Total No. of utterances" in Tables 4 through 8 indicates the total number of utterances of all base subjects.

In order to investigate the effect of age difference on sentence-final speech levels, the mean percentages of each speech level with different interlocutors were investigated, as shown in Figure 1. This was compared with those that exclude non-marked utterances (NM) in order to look more closely at the function of non-marked utterances (NM) (please see Figure 2).

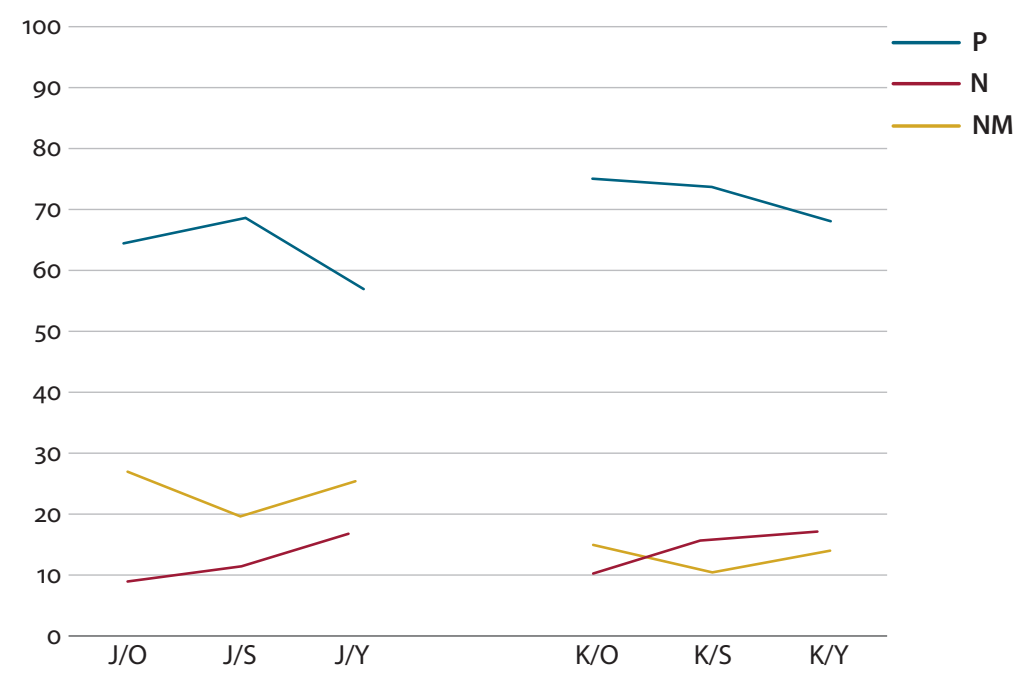

Figure 1. Percentage of sentence-final speech levels with interlocutors of different ages in Japanese and Korean 
For Japanese, Figure 1 indicates that the percentage of polite forms $(\mathrm{P})$ is highest in conversations with interlocutors of the same age. There was a significant difference in the use of polite forms $(\mathrm{P})$ depending on the interlocutor's age $(F(2,27)=4.512$, $p<0.05)$. Moreover, the base subjects used polite forms $(\mathrm{P})$ significantly more when speaking to interlocutors of the same age than when speaking to younger interlocutors $(p<0.05)$. This result is inconsistent with Brown and Levinson's politeness theory (1987) which postulates that more polite linguistic forms tend to be used with older interlocutors, who have the greatest power from the base, as long as all other factors are kept constant. The reason why base subjects use polite forms $(\mathrm{P})$ primarily toward the same age interlocutors may be related to the use of non-marked utterances (NM), which will be discussed in detail below.

In the Korean language, on the contrary, the percentage of polite forms $(\mathrm{P})$ is highest for older interlocutors, followed by for interlocutors of the same age, then for younger interlocutors. There was a significant difference in the use of the polite forms $(\mathrm{P})$ depending on the interlocutor's age $(F(2,27)=7.360, p<0.01)$. In particular, the base subjects used polite forms $(\mathrm{P})$ significantly more when speaking to older interlocutors and same age interlocutors than when speaking to younger interlocutors ( $p<0.01$ and $p<0.05$, respectively). This result implies that the usage of the polite forms $(\mathrm{P})$ reflects hierarchical relationships based on the interlocutor's age. The non-polite forms $(\mathrm{N})$ are in inverse proportion to the age of the interlocutor in both languages. In addition, there was a significant difference in the use of the non-polite forms $(\mathrm{N})$ depending on the interlocutor's age in both languages $(F(2,27)=4.031, p<0.05$ for Japanese, and $F(2,27)=23.520, p<0.001$ for Korean). For Japanese speakers in particular, the base subjects used non-polite forms $(\mathrm{N})$ significantly more when speaking to younger interlocutors than when speaking to older interlocutors $(p<0.05)$. For the Korean speakers, the base subjects used non-polite forms $(\mathrm{N})$ significantly more when speaking to the same-age and younger interlocutors than when speaking to older interlocutors $(p<0.001$ and $p<0.001$, respectively). As Usami (2002) pointed out, these results may suggest that only non-polite forms $(\mathrm{N})$ at the "sentence-final speech levels" reflect the hierarchical relationships between speakers for Japanese, whereas both the polite forms $(\mathrm{P})$ and the non-polite forms $(\mathrm{N})$ have the same effect for those in Korean. In addition, these results indicate that Korean has a stronger tendency to explicitly preserve the normative use of honorifics by linguistic forms at the sentence-final speech levels, compared to Japanese.

As far as non-marked utterances (NM) are concerned, the percentage in both languages is relatively high for conversations with interlocutors of different ages. There was a significant difference in the use of the non-polite forms $(\mathrm{N})$ depending on the interlocutor's age in both languages $(F(2,27)=7.031, p<0.01$ for Japanese, and $F(2,27)=4.017, p<0.05$ for Korean). The Japanese base subjects 
used non-marked utterances (NM) significantly more when speaking to older and younger interlocutors than when speaking to same-age interlocutors $(p<0.01$ and $p<0.05$ respectively). For the Korean speakers, the base subjects used non-marked utterances (NM) significantly more when speaking to older interlocutors than when speaking to same-age interlocutors $(p<0.05)$. Most of the non-marked utterances (NM) are incomplete and thus, indirect. Thus, it could be assumed that the subjects speak more explicitly and directly in conversations with interlocutors of the same age. When compared with Korean, Japanese uses non-marked utterances (NM) more frequently in conversations with interlocutors of different ages. Based on the collective results, it could be deduced that the percentage of polite forms (P) becomes lower due to the increase of non-marked utterances (NM) in conversations with interlocutors of different ages.

Now, I can explain why the polite forms (P) in Japanese, or the unmarked speech level in conversations between new acquaintances, is mostly used for interlocutors of the same age. Conventional wisdom stipulates that the polite forms $(\mathrm{P})$ should be used when talking to new acquaintances. However, when talking with interlocutors of different ages, the speakers tend to avoid showing hierarchical relationships based on age by using non-marked utterances (NM) instead of the polite forms $(\mathrm{P})$ or the non-polite forms $(\mathrm{N})$. In contrast, when speakers are talking with same-age interlocutors, they do not need to avoid hierarchical relationships based on age. Similar to the findings of Usami's studies (2001a; 2002) on the speech levels of Japanese females, these results suggest that non-marked utterances (NM) have a function of making hierarchical less defined. Therefore, it can be stated that the three categories of speech levels (polite forms (P), non-polite forms $(\mathrm{N})$ and non-marked utterances (NM)) are interrelated and non-marked utterances (NM) can be used as a substitute for another.

As stated above, speech levels, excluding non-marked utterances (NM), were recalculated and shown in Figure 2 in order to examine the functions of non-marked utterances (NM) more explicitly. Figure 2 indicates that the polite forms $(\mathrm{P})$ are roughly proportional to the age of the interlocutors, and that the usage of the polite forms $(\mathrm{P})$ in both languages reflects the hierarchical relationships based on the age of the interlocutors. In both languages, there was a significant difference in the use of the polite forms $(\mathrm{P})$ depending on the interlocutor's age $(F(2,27)=4.093$, $p<0.05$ for Japanese, and $F(2,27)=22.461, p<0.001$ for Korean). In particular, Japanese base subjects used polite forms $(\mathrm{P})$ significantly more when speaking to older interlocutors than when speaking to younger interlocutors $(p<0.05)$. The Korean base subjects used polite forms $(\mathrm{P})$ significantly more when speaking to older interlocutors than when speaking to the same-age and younger interlocutors $(p<0.001$ and $p<0.001$, respectively). In both languages, the increase in polite forms $(\mathrm{P})$ is more explicit for conversations with older interlocutors. And, when 


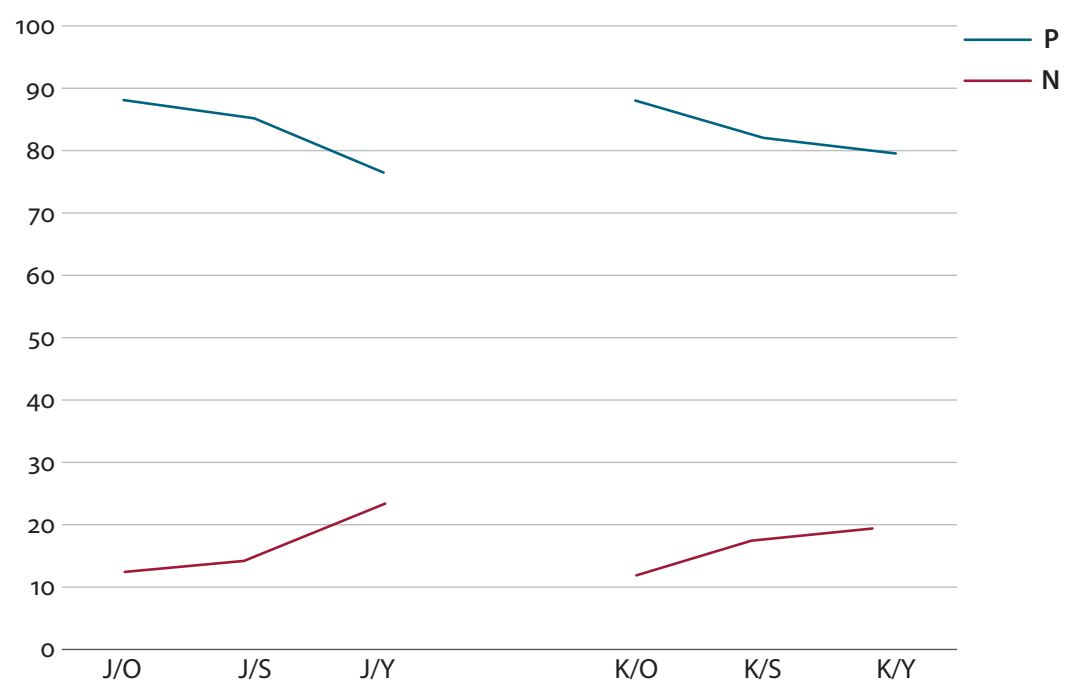

Figure 2. Percentage of sentence-final speech levels excluding NM with interlocutors of different ages in Japanese and Korean

compared with Korean, Japanese shows a noticeable increase in the percentage of polite forms (P) for conversations with older interlocutors. Nevertheless, uses of non-polite forms $(\mathrm{N})$ in both languages are roughly inversely proportional to the age of the interlocutors. In both languages, there was a significant difference in the use of the non-polite forms $(\mathrm{N})$ depending on the interlocutor's age $(F(2,27)=4.082$, $p<0.05$ for Japanese, and $F(2,27)=22.461, p<0.001$ for Korean). Particularly Japanese base subjects used non-polite forms $(\mathrm{N})$ significantly more when speaking to younger interlocutors than when speaking to older interlocutors $(p<0.05)$. The Korean base subjects used non-polite forms $(\mathrm{N})$ significantly more when speaking to the same-age and younger interlocutors than when speaking to older interlocutors ( $p<0.001$ and $p<0.001$, respectively). These results clearly show that both Japanese and Korean reflect hierarchical relationships based on age between speakers by using the polite forms $(\mathrm{P})$ and the non-polite forms $(\mathrm{N})$ at "sentence-final speech levels".

In order to deduce the function of non-marked utterances (NM), the effect of interlocutors' age on polite forms $(\mathrm{P})$ and non-polite forms $(\mathrm{N})$ including and excluding non-marked utterances (NM) as a form of speech level was analyzed. When non-marked utterances (NM) was included in the analysis, the effect of interlocutors' age on polite forms $(\mathrm{P})$ and non-polite forms $(\mathrm{N})$ seemed ambiguous, especially for Japanese. For example, polite forms $(\mathrm{P})$ was highest between same age interlocutors' conversation for Japanese. However, as many previous studies have done, when non-marked utterances (NM) was excluded in the analysis, 
the interlocutor's age clearly influenced speech level of base subject as shown in Figure. 2: polite forms (P) was highest against older interlocutor, followed by same age and younger interlocutors for Japanese. Though the trend is relatively weaker, a similar result related with non-marked utterances (NM) was observed in analysis of Korean conversation. These findings suggest that non-marked utterances (NM) in "sentence-final speech levels" make hierarchical relationships seem ambiguous. Although hierarchical relationships are supposed to be marked by speech levels in the honorific system, Japanese seems to use non-marked utterances (NM) effectively, even if subconsciously, in order to avoid acknowledging hierarchical relationships between speakers. In particular, it was also believed that non-marked utterances (NM) could only partly replace the polite forms (P) in a Japanese conversation with an older interlocutor, which may be referred to as an "honorific avoidance strategy" suggested by Neustupny (1983). According to his study, speakers sometimes avoid using honorifics in order to break ice and to control their deference toward interlocutors to decrease psychological distance between them; this was termed as "honorific avoidance strategy". He also suggested that omitting the predicate with the politeness marker is one of the major strategies for this purpose. The function of non-marked utterances (NM) in the conversation controlled by age can be explained as follows. When talking with older interlocutor, the base subjects try not to use polite forms $(\mathrm{P})$ to both avoid acknowledging hierarchical relationships and reduce psychological distance. However, the base subjects also have desire not to be rude to older interlocutor caused by the use of non-polite forms (N). Accordingly, the base subjects choose non-marked utterances (NM); this includes no sentence-final linguistic markers of the politeness showing attitude such as respect or deference of a speaker to an addressee. On the contrary, the base subjects who converse with younger interlocutors tend to avoid using non-polite forms $(\mathrm{N})$ which can be attributed to first meeting formality. Interestingly, however, non-marked utterances (NM) was used to avoid increasing psychological distance caused by the use of polite forms (P). By adopting Brown and Levinson's politeness theory (1987), it can be asserted that non-marked utterances (NM) function as a politeness strategy for smooth communication by satisfying positive face and not threatening negative face. In brief, non-marked utterances (NM) mitigates the speaker to acknowledge the hierarchical relationships, inevitably indicated by choosing the politeness level of linguistic forms, such as polite forms (P) and non-polite forms $(\mathrm{N})$, and the use of non-marked utterances (NM) seems to be related to function as politeness strategies.

In summary, the polite forms $(\mathrm{P})$ and the non-polite forms $(\mathrm{N})$ at the sentence-final speech levels in Korean reflect hierarchical relationships based on age between speakers compared to those in Japanese. Therefore, it could be concluded that Korean has a strong tendency to preserve the normative honorific usage 
of polite forms toward older people, whereas Japanese tends not to clearly show the hierarchical relationships based on age difference at the sentence-final speech levels by using NM. It should be emphasized that these functions of speech levels can be exposed by the integrated analysis of speech levels including non-marked utterances (NM) as well as polite forms $(\mathrm{P})$ and non-polite forms $(\mathrm{N})$ in an integrated way at the discourse level, as conducted in this study.

\subsection{2 "Speech levels in the whole utterance" when "sentence-final speech levels" are NM}

As indicated in the above section, NM has an important function as a strategy to convey politeness. In this section, when "sentence-final speech levels" are NM, the uses of "speech levels in the whole utterance" and their functions at the discourse level are investigated in detail. The average percentage of "speech levels in the whole utterance" for the case is shown in Table 5. The table shows that the percentage of $\mathrm{NM}$ at the "speech levels in the whole utterance" is the highest in both languages. The percentage of polite forms $(\mathrm{P})$ in Japanese turned out to be much higher than that in Korean, yet, the percentages of non-polite forms $(\mathrm{N})$ for the two languages exhibit an opposite tendency.

Table 5. Frequency and percentage of "speech levels in the whole utterance" when "sentence- final speech levels" are NM in Japanese and Korean

\begin{tabular}{|c|c|c|c|c|c|c|c|c|c|}
\hline \multirow[t]{2}{*}{ Language } & \multicolumn{2}{|l|}{$S$} & \multicolumn{2}{|l|}{$\mathrm{P}$} & \multicolumn{2}{|l|}{$\mathrm{N}$} & \multicolumn{2}{|l|}{ NM } & \multirow{2}{*}{$\begin{array}{l}\text { Total No. of } \\
\text { utterances }\end{array}$} \\
\hline & No. & $\begin{array}{l}\text { Percent } \\
(\%)\end{array}$ & No. & $\begin{array}{l}\text { Percent } \\
(\%)\end{array}$ & No. & $\begin{array}{l}\text { Percent } \\
(\%)\end{array}$ & No. & $\begin{array}{l}\text { Percent } \\
(\%)\end{array}$ & \\
\hline Japanese & 31 & 6.7 & 66 & 14.2 & 129 & 27.7 & 239 & 51.4 & 465 \\
\hline Korean & 29 & 8.9 & 19 & 5.8 & 126 & 38.7 & 162 & 49.7 & 326 \\
\hline
\end{tabular}

Example (1) below shows the use of the polite form "desu 'copula" in the middle of sentences when the sentence-final speech level is NM ("shukudai wa...'(How's) homework'”) in No 132, spoken by JBM1. For example, line 132 shows P in speech levels in the whole utterance with sentence-final speech level of NM. Example (2) shows when super-polite form - the humble form "jeo 'we"- is used in the middle of sentence when the sentence-final speech level is NM ("gyeongyeonghakkkwa...'business management'”) in No 10, spoken by KBM3. For example, line 10 has $S$ in speech levels in the whole utterance with sentence-final speech level of NM. Although the interlocutors in both examples are older people, the sentence-final speech levels are NM, or in other words, do not show politeness toward the interlocutors. Instead, politeness is conveyed implicitly through the use of polite forms and humble forms in the middle of sentences. 
Example 1.

132 JBM1 ヘー、長い夏休みですが、宿題は...<笑い>。

He-, nagai natsuyasumi desu ga, shukudai wa...<warai>.

(Eh - , It's a long summer vacation. How's homework?

$<$ laughter>)

133 JOF4 あ、子供達ですか?。

A, kodomotachi desu ka?

(Oh, you mean children?)

134 JBM1 はい。

Hai.

(Yes.)

135 JOF4 宿題は今はもうほとんど出さないんです。

Shukudai wa ima wa hotondo dasa nain desu.

(Not much homework is given these days.)

Example 2.

$9 \mathrm{KOM} 2$ 독일어과 나왔<습니다> $\{<\}$.

Dogireokkwa nawa $<$ sseummida $>\{<\}$.

(I majored in German)

$10 \mathrm{KBM} 3<$ 네->\{>\}, 저두 경영학과...

$<\mathrm{Ne}->\{>\}$, jeodu gyeongyeonghakkkwa...

(I see. I majored in business management.)

11 KOM2 아-, 그래요?.

A-, geuraeyo?

(Oh, did you?)

Figure 3 presents the average percentage of speech levels in the whole utterance with different interlocutors where "sentence-final speech levels" are NM.
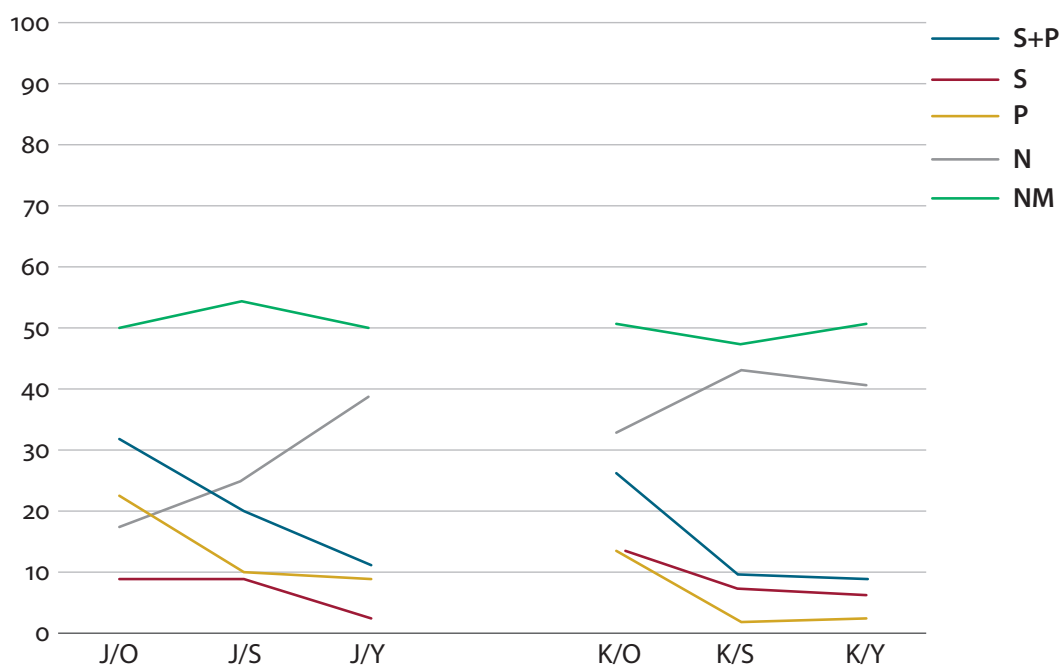

Figure 3. Percentage of speech levels in the whole utterance with interlocutors of different ages when "sentence-final speech levels" are NM in Japanese and Korean 
The percentage of super-polite forms $(S)$ is in proportion to the age of the interlocutor in both languages. However this tendency is stronger in Korean than in Japanese, and this result may be due to the difference in linguistic behaviors between those who speak Japanese and Korean. For Japanese, super-polite forms (S) represent the speaker's sophistication or personal inclination to use more polite forms as well as their actual respect to a specific addressee, reported in previous studies (e.g., Ide 1997; Usami 2001a). Inversely, super-polite forms (S) in Korean have the function of showing actual respect to a specific addressee. There was a significant difference in the use of super-polite forms (S) depending on the interlocutor's age in both languages $(F(2,27)=8.044, p<0.01$ for Japanese, and $F(2,27)=7.360, p<0.01$ for Korean). In particular, Japanese base subjects used super-polite forms (S) significantly more when speaking to older interlocutors and the same-age interlocutors than when speaking to younger interlocutors ( $p<0.01$ and $p<0.01$, respectively). On the other hand, Korean base subjects used super-polite forms (S) significantly more when speaking to older interlocutors than when speaking to the same-age and younger interlocutors $(p<0.01$ and $p<0.01$, respectively). As for the polite forms $(\mathrm{P})$, their percentage is in proportion to the age of the interlocutor in Japanese, whereas it is highest in conversations with older interlocutors in Korean, but not proportional to the age of interlocutors. There was a significant difference in the use of polite forms $(\mathrm{P})$ depending on the age of the interlocutor in both languages $(F(2,27)=8.848, p<0.01$ for Japanese, and $F(2,27)=9.137, p<0.01$ for Korean). Specifically, the base subjects used polite forms $(\mathrm{P})$ significantly more when speaking to older interlocutors than when speaking to the same-age and younger interlocutors in both languages $(p<0.05$ and $p<0.01$, respectively, for Japanese, and $p<0.01$ and $p<0.01$, respectively, for Korean). Interestingly, the formal forms $(\mathrm{S}+\mathrm{P})$ consisting of super-polite forms (S) and polite forms (P) are clearly in proportion to the age of the interlocutor. There was a significant difference in the use of formal forms $(\mathrm{S}+\mathrm{P})$ depending on the interlocutor's age in both languages $(F(2,27)=12.701, p<0.01$ for Japanese, and $F(2,27)=17.234, p<0.001$ for Korean). Japanese base subjects used formal forms $(\mathrm{S}+\mathrm{P})$ significantly more when speaking to older interlocutors and same-age interlocutors than when speaking to younger interlocutors $(p<0.001$ and $p<0.05$, respectively). For the Korean language, the base subjects used formal forms $(\mathrm{S}+\mathrm{P})$ significantly more when speaking to older interlocutors than when speaking to the same-age and younger interlocutors ( $p<0.001$ and $p<0.001$, respectively). As for non-polite forms $(\mathrm{N})$, their percentage is in inverse proportion to the age of interlocutors in Japanese, whereas it is lowest in conversations with older interlocutors but not inversely proportional to the age of interlocutors in Korean. There was a significant difference in the use of non-polite forms $(\mathrm{N})$ depending on the interlocutor's age in Japanese $(F(2,27)=32.008, p<0.001)$. Specifically, the base 
subjects used non-polite forms $(\mathrm{N})$ significantly more when speaking to younger interlocutors than when speaking to older interlocutors $(p<0.001)$. In short, Japanese conspicuously reflects hierarchical relationships based on the age of interlocutors in the usage of the super-polite forms(S), polite forms $(\mathrm{P})$, and non-polite forms $(\mathrm{N})$, while Korean achieves this relation by using the super-polite forms $(\mathrm{S})$ and polite forms $(\mathrm{P})$.

Based on the findings in this section, it could be suggested that when "sentence-final speech levels" are NM, the hierarchical relationships are reflected in the honorific language usage of super-polite forms (S), polite forms (P), and etc. in the "speech levels in the whole utterance" in both languages. Through these various manipulations of speech levels, both Japanese and Korean implicitly conform to the traditional principles of honorifics - that is, using more polite linguistic forms toward older people. In other words, speech levels could be manipulated strategically between speakers in order to show consideration for interlocutors; this tendency appears to be stronger in Japanese than in Korean based on the finding in this study. ${ }^{7}$

\subsection{Speech level shifts}

\subsubsection{Speech level shifts}

Table 6 shows the frequency and percentage of each speech level shift in Japanese and Korean.

Table 6. Frequency and percentage of speech level shifts in Japanese and Korean

\begin{tabular}{|c|c|c|c|c|c|c|c|}
\hline \multirow[t]{2}{*}{ Language } & \multicolumn{2}{|c|}{ Downshift (D) } & \multicolumn{2}{|c|}{ Upshift (U) } & \multicolumn{2}{|c|}{ No-shift (N) } & \multirow{2}{*}{$\begin{array}{l}\text { Total No. of } \\
\text { utterances }\end{array}$} \\
\hline & No. & Percent (\%) & No. & Percent (\%) & No. & Percent (\%) & \\
\hline Japanese & 204 & 10.5 & 177 & 9.1 & 47 & 2.4 & 1,951 \\
\hline Korean & 296 & 11.8 & 362 & 14.4 & 80 & 3.2 & 2,516 \\
\hline
\end{tabular}

* This indicates the total number of utterances of all bases.

The percentage of each speech-level shift, downshift (D), upshift (U), and no-shift $(\mathrm{N})$ in Korean is higher than that of Japanese, and this result might reflect the fact that Korean uses the non-polite forms (N) more frequently than Japanese. For Japanese, the percentage of downshift (D) is higher than that of the upshift (U), yet, Korean exhibits the opposite trend. As expected, Korean tends to show clear

7. There are other strategies that could be manipulated to show consideration for others, but are beyond the scope of this study. These include noun and adjective choices, and non-verbal behaviors such as gesture and physical distance. 
hierarchical relationships between speakers, which makes it sensitive to the use of sentence-final speech level. Accordingly, Korean has a strong tendency to revert to the polite forms (P), the dominant (unmarked) speech level, immediately once the speech level is downshifted (D).

The percentages of speech level shifts with different interlocutors are shown in Figure 4.

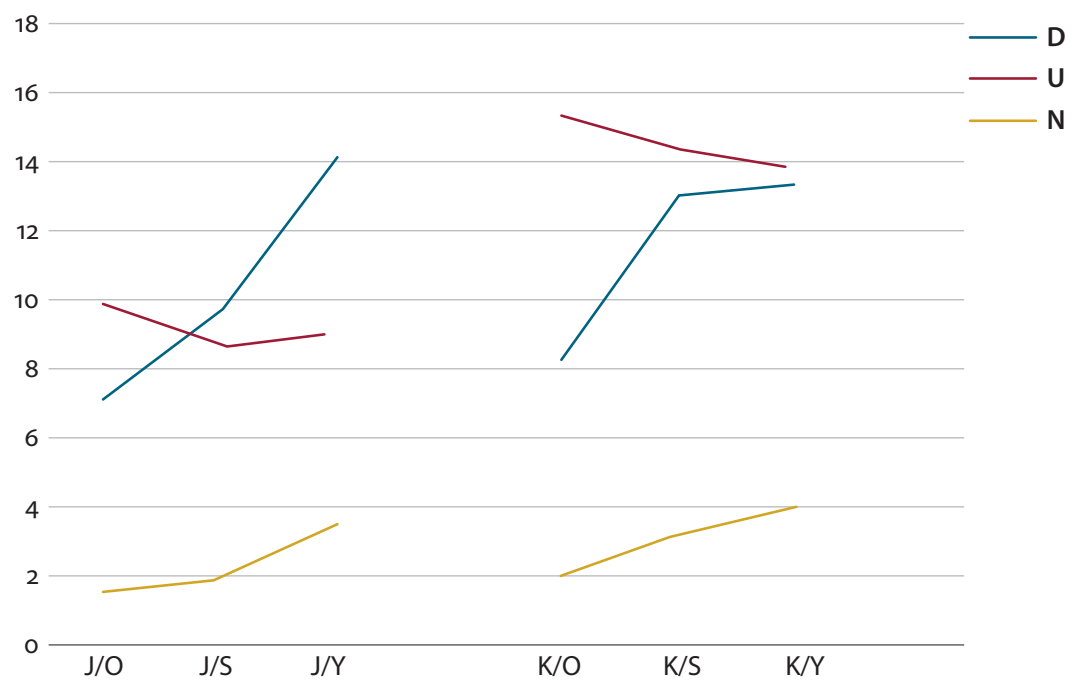

Figure 4. Percentage of speech level shifts with interlocutors of different ages in Japanese and Korean

For both Japanese and Korean, the percentage of downshift (D) is lowest for older interlocutors and highest for younger ones. There was a significant difference in the use of downshift (D) depending on the interlocutor's age in both languages $(F(2,27)=4.431, p<0.05$ for Japanese and $F(2,27)=5.830, p<0.01$ for Korean $)$. The Japanese base subjects used downshift (D) significantly more when speaking to younger interlocutors than when speaking to older interlocutors $(p<0.05)$. The Korean base subjects used downshift (D) significantly more when speaking to the same-age and younger interlocutors than when speaking to older interlocutors $(p<0.05$ and $p<0.05$, respectively). No-shift $(\mathrm{N})$ shows a similar tendency to the downshift; it is highest for younger interlocutors. There was a significant difference in the use of no-shift $(\mathrm{N})$ depending on the interlocutor's age in both languages $(F(2,27)=4.225, p<0.05$ for Japanese and $F(2,27)=5.135, p<0.05$ for Korean). In both languages, the base subjects used no-shift $(\mathrm{N})$ significantly more when speaking to younger interlocutors than when speaking to older interlocutor $(p<0.05$ and $p<0.05$, respectively). Since base subjects often use the non-polite forms when 
talking with younger interlocutors who are inferior in power, the downshift (D) and no-shift $(\mathrm{N})$ tend to occur more frequently in conversations with younger interlocutors. Both languages also show another common trait: the percentage of upshift (U) being the highest in conversations with older interlocutors.

For Japanese, an interesting tendency regarding speech level shifts with age differences was observed. For conversations with older interlocutors, a strong tendency of immediately reverting to the unmarked (dominant) speech level, the polite form (upshift (U)), was observed once the speech level had been downshifted. On the other hand, for conversations with younger interlocutors, a mild tendency to remain at the marked speech level, the non-polite form (no-shift $(\mathrm{N})$ ), was observed, although the speech level had been downshifted. Consequently the traditional principle of honorifics, in which younger people generally show more polite linguistic behavior toward older interlocutors in both languages, is well reflected in the speech level shifts. These results are consistent with of Brown and Levinson (1987) who assert that one's linguistic behavior is strongly dependent on power variables such as interlocutor's age or social status, under the condition that the distance variable and rank of imposition remain constant. Also, according to their politeness theory, the speech level shift functions as a politeness strategy for smoothing communication through a downshift or no-shift satisfying positive face, or an upshift satisfying negative face.

\subsubsection{Politeness effects of downshift}

Since the polite form was found to be the "unmarked behavior (dominant speech level)" in this study, the downshift to a non-polite form in conversations between unacquainted persons is considered as "marked behavior". In this section, the "politeness effects" of the downshift, the marked behavior, was investigated from the viewpoint of discourse politeness. The average percentage for this is shown in Table 7.

Table 7. Frequency and percentage of the politeness effects of downshift in Japanese and Korean

\begin{tabular}{|c|c|c|c|c|c|c|c|}
\hline \multirow[t]{2}{*}{ Language } & \multicolumn{2}{|c|}{$\begin{array}{l}\text { Plus politeness } \\
\text { effects (PP) }\end{array}$} & \multicolumn{2}{|c|}{$\begin{array}{l}\text { Neutral politeness } \\
\text { effects (NP) }\end{array}$} & \multicolumn{2}{|c|}{$\begin{array}{l}\text { Minus politeness } \\
\text { effects (MP) }\end{array}$} & \multirow[t]{2}{*}{$\begin{array}{l}\text { Total no. of } \\
\text { utterances }\end{array}$} \\
\hline & No. & Percent(\%) & No. & Percent(\%) & No. & Percent(\%) & \\
\hline Japanese & 65 & 31.9 & 139 & 68.1 & 0 & 0.0 & 204 \\
\hline Korean & 122 & 41.2 & 174 & 58.8 & 0 & 0.0 & 296 \\
\hline
\end{tabular}

\footnotetext{
* This indicates the total number of utterances in speech-level shifts that took place.
} 
It is generally known that the downshift has one of three politeness effects: plus politeness effects, neutral politeness effects, or minus politeness effects. In this study, only two politeness effects of downshift were observed in both languages: "plus politeness effects (PP)" and "neutral politeness effects (NP)" as shown in Table 7. The reason for the absence of "minus politeness effects (MP)" could be explained by participants did not care to be rude in a formal situation, which is a characteristic of the first conversation between unacquainted persons. The follow-up questionnaire survey also confirmed few possibilities for "minus politeness effects (MP)". The questionnaire survey included the following questions: (1) Did you feel any impoliteness in your interlocutor's manner of speaking and/or attitude? (2) Did you feel any discomfort about your interlocutor's manner of speaking and/or attitude? All of the subjects answered "not at all" to the two questions. Table 8 shows that both Japanese and Korean have a higher percentage of "neutral politeness effects (NP)" than that of "plus politeness effects (PP)". In particular, such a tendency is more distinct in Japanese. The "plus politeness effects (PP)" and "neutral politeness effects (NP)" were classified according to their context in utterances when downshift occurred, as shown in Table 8.

Table 8. Frequency and percentage of contents of utterance when downshift occurs in Japanese and Korean

\begin{tabular}{llcc}
\hline Contents of utterance & & Japanese & Korean \\
\hline Plus Politeness effects (PP) & Intimacy & $27(13.2)$ & $65(22.0)$ \\
$\rightarrow$ Psychological context & Sympathy & $38(18.6)$ & $57(19.3)$ \\
\hline Neutral Politeness effects (NP) & Monologue & $30(14.7)$ & $22(7.4)$ \\
$\rightarrow$ Linguistic context & Asking information or confirmation & $27(13.2)$ & $45(15.2)$ \\
& Providing information, response & $56(27.5)$ & $74(25.0)$ \\
& Topic switching & $26(12.7)$ & $33(11.1)$ \\
Total $^{* *}$ & & $204(100.0)$ & 296(100.0)
\end{tabular}

\footnotetext{
* By psychological context, I refer to the situation where a speaker controls psychological distance by expressing intimacy or sympathy toward talking partner (PP), or uncomfortable or unpleasant feeling against talking partner (MP).

** This indicates the total number of utterances in which speech-level shifts take place.
}

The "plus politeness effects (PP)" shown in Table 8 is used to show intimacy through a joke or a compliment; this maintains the interlocutor's speech level and expresses sympathy. The "neutral politeness effects (NP)" is used for a monologue, seeking or providing information, and introducing a new topic. Accordingly, PP is thought to occur in a psychological context, by controlling psychological distance to express closeness and friendliness toward the interlocutor. NP is in a linguistic context which allows for the conversation to proceed effectively. These results imply that the tendency for a downshift is more commonly used in the linguistic context rather 
than in the psychological context in first-meeting conversations, in which the polite form is an unmarked speech level (dominant speech level).

Example (3) is the case of "plus politeness effects (PP)" of downshift in Korean conversations. In this conversation, the base, KBM3, downshifted a polite form (P) in line 140 to a non-polite form $(\mathrm{N})$ in line 141 . KBM3 is expressing his compliment on the company which KYM2 is working for. This compliment, which accompanied with laughter, could imply envious feelings and admiration for the interlocutor in Korean conversation, which could reduces the distance between the two interlocutors and make favorable mode. Therefore, this downshift is thought to function as "plus politeness effects (PP)".

Example 3.

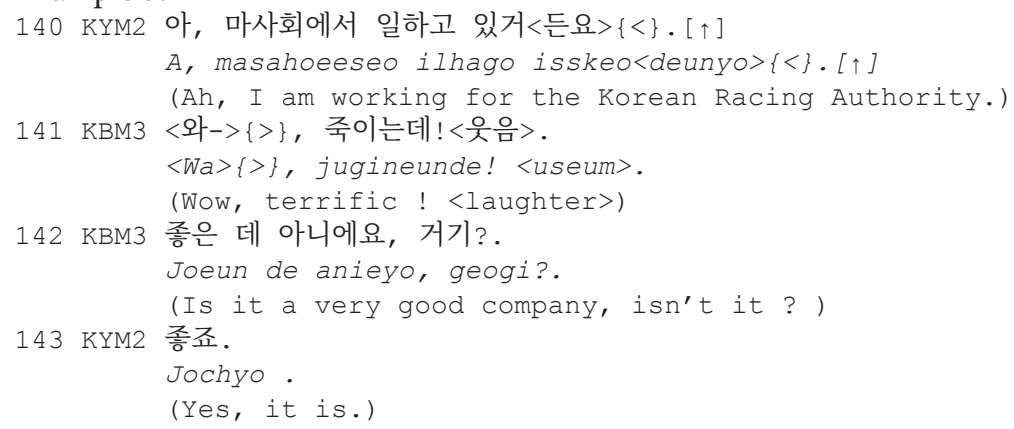

Example (4) is the case of "neutral politeness effects (NP)" of downshift in Japanese conversations. In this conversation, the base, JBM3, downshifted a polite form (P) in line 101 to a non-polite form (N) in line 102 by repeating part of the interlocutor's utterance, "Batoru 'Battle" in the response to JYM4's utterance in line 101, "Batoru desu kedo 'Although it is a sort of battle to...." The downshift in this situation is a monologue, repeating JYM4's utterance, and is considered to be an example of a "neutral politeness effects (NP)"; that is, it is neither particularly polite nor unpleasant.

Example 4.

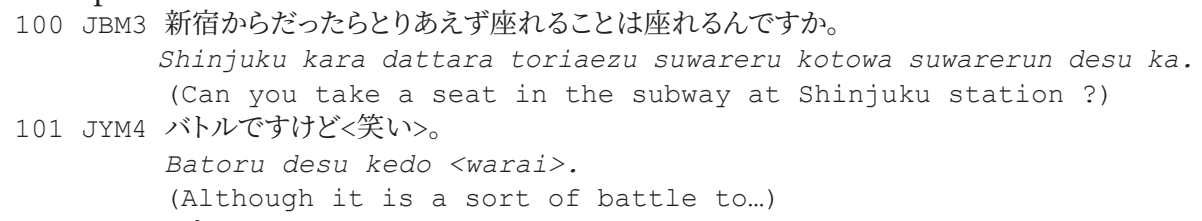

103 JBM3 や、座れると座れないじゃ大違いでしょ。

Ya, suwareru to suware nai ja ōchigai desho.

(Taking a seat in the subway is quite important, isn' it ?) 


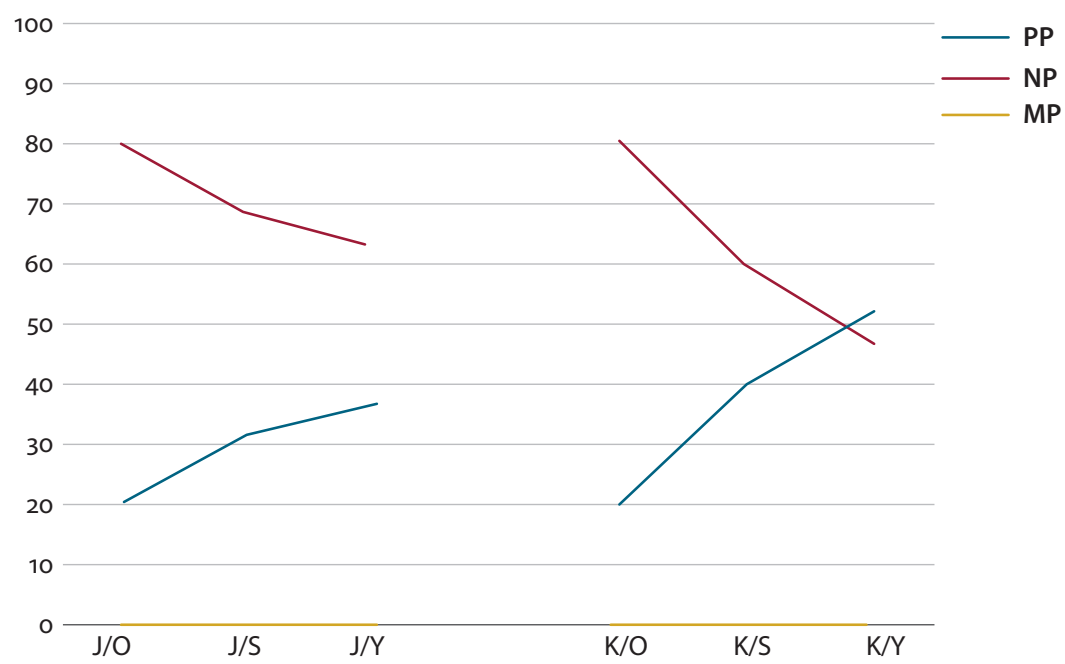

Figure 5. Percentage of "politeness effects" of downshift with interlocutors of different ages in Japanese and Korean

In both languages, the percentage of "plus politeness effects (PP)" of downshift is in inverse proportion to the age of the interlocutor, whereas the percentage of "neutral politeness effects (NP)" of downshift is in proportion to the age of the interlocutor. There were significant differences in the uses of plus politeness effects (PP) and neutral politeness effects (NP) depending on the interlocutor's age in both languages $(F(2,27)=11.378, p<0.001$ and $F(2,27)=11.378, p<0.001$, respectively, for Japanese, and $F(2,27)=20.889, p<0.001$ and $F(2,27)=20.889$, $p<0.001$, respectively, for Korean). The Japanese base subjects used plus politeness effects (PP) significantly more when speaking to younger interlocutors than when speaking to older interlocutors $(p<0.001)$, and used neutral politeness effects (NP) significantly more when speaking to older interlocutors than when speaking to younger interlocutors $(p<0.001)$. The Korean base subjects used plus politeness effects (PP) significantly more when speaking to the same-age and younger interlocutors than when speaking to older interlocutors $(p<0.01$ and $p<0.001$, respectively), and when speaking to the same-age interlocutors than when speaking to younger interlocutors $(p<0.05)$. Moreover, the Korean base subjects used neutral politeness effects (NP) significantly more when speaking to older interlocutors than when speaking to the same-age and younger interlocutors $(p<0.01$ and $p<0.001$, respectively) and when speaking to the same-age interlocutors than when speaking to younger interlocutors $(p<0.05)$. Recalling Table 8, Figure 5 can be interpreted in a different way: the downshift is more frequently used in the linguistic context in conversations with older interlocutors, whereas it is more frequently used in the 
psychological context with younger interlocutors. ${ }^{8}$ This study shows that the function of the non-polite forms $(\mathrm{N})$ in conversations from the perspective of "politeness effects" is dependent on the hierarchical relationships between the participants, even if the non-polite forms (N) itself is just a type of speech levels in terms of linguistic forms. Therefore, it can be emphasized that the function of downshifts, especially in this case the "politeness effects", can be exposed effectively by analysis at the discourse level.

\section{Conclusions}

This study analyzed the uses and functions of speech levels and speech level shifts in natural conversations between two unacquainted males; both similarities and differences between Japanese and Korean have been investigated. The results are briefly summarized as follows.

Regarding the speech levels in the Japanese language, at the "sentence-final speech levels", it is the use of the non-polite forms, a deviation from the normative or dominant politeness level of linguistic forms that conspicuously reflects the hierarchical relationships between the two speakers. On the other hand, the polite forms are used most frequently in conversations with same-age interlocutors. The percentage of "non-marked utterances (NM)" is higher in conversations with interlocutors who are either older or younger. When the use of "sentence-final speech levels" is considered as a whole, it can be deduced that "non-marked utterances (NM)" in "sentence-final speech levels" functions to avoid acknowledging hierarchical relationships explicitly by using politeness markers such as polite forms and non-polite forms. However, for "speech levels in the whole utterance" when the "sentence-final speech levels" are NM, formal forms that include super-polite forms (S) and polite forms $(\mathrm{P})$, are proportionally used, whereas non-polite forms $(\mathrm{N})$ are used in an inverse proportion to the age of the interlocutor. When "sentence-final speech levels" are NM, the use of "speech levels in the whole utterance" reflects the hierarchical relationships between speakers whereas "sentence-final speech levels" on their own do not clearly show the age differences between interlocutors. These results imply that modern Japanese people have a tendency not to clearly show the hierarchical relationships between speakers with linguistic forms in the "sentence-final speech levels". However, the choice of "speech levels in the whole utterance" still reflects hierarchical relationships between speakers. On the whole, although hierarchical relationships between speakers appear less prevalent in Japanese conversations,

8. The ratio of psychological context of intimacy was higher than that of sympathy when taking with younger interlocutors for both languages: 55.6\% for Japanese and 60.3\% for Korean. 
the choice of "speech levels in the whole utterance" still indirectly reflects their tendency to preserve the use of honorifics. On the other hand, speech level shifts strategically reflect hierarchical relationships of interlocutors of different ages. This means speech level shifts are manipulated depending on the interlocutor's age. Downshift and no-shift, which deviate slightly from the normative language, reflect the speaker's strategic language use, whereas an upshift reflects the speaker's preference to adhere to the use of normative language. In addition, "politeness effects" of downshift strategically reflect hierarchical relationships based on the interlocutor's age.

In contrast with the Japanese language, the Korean language exhibits both speech levels and speech level shifts are positively correlated with the age of the interlocutors; they clearly reflect hierarchical relationships based on the age of the interlocutors. The polite forms (P) and the non-polite forms (N) in the "sentence-final speech levels" as well as the super-polite forms $(\mathrm{S})$ and the polite forms $(\mathrm{P})$ in the "speech levels in the whole utterance" clearly reflect hierarchical relationships between speakers. In contrast to the Japanese speakers in this study, these results suggest that Korean has a stronger tendency to preserve the normative use of honorifics explicitly in linguistic forms and sentence-final speech levels.

In short, the Korean base subjects in this study preserved the normative honorific usage of polite forms toward older people, whereas the Japanese base subjects seemed to avoid speech levels that highlight hierarchical relationships embedded in honorific systems. However, both languages conform well to the normative language use, strategically at the discourse level including sentence/utterance-level. These results indicate that speech levels, considered to be socio-pragmatically obligatory, have a strategic-use aspect for both languages at the discourse level: the use of "non-marked utterances (NM)" and downshift, the deviation from the normative speech level. These results indicate that Japanese use speech levels more strategically than Korean. Although both languages have a similar honorific system, they exhibit some differences in the first encounter conversations. This could be attributed to their socio-cultural differences. Japan adopted an ideal of equality from western countries much earlier than Korea, where the Confucian ideology still prevails. Because of this, Japanese uses honorifics strategically to evade hierarchical relationships based on age, while Korean tends to conform to social norms based on the Confucianism principles that emphasize politeness toward older people. As a result, younger people use polite forms to their elders. These results empirically confirm the other previous research by Takiura (2005) who observed that Korean people tend to adhere more strongly to absolute honorifics compared to the Japanese.

In this study, politeness strategies in Japanese and Korean conversations between males were analyzed focusing on speech levels and speech level shifts. More research into the analysis including consecutive ups and downs, sequential 
contingencies, interlocutors' intentions, orientations and group dynamism can contribute to a more complete understanding of discourse-level shifts of the politeness phenomenon, which will be my next research topic. It is hoped that this study has provided a deeper insight into actual language use as well as into the usage of honorific language systems in first encounter conversations, and will serve as a useful reference for cross-cultural pragmatics and interpersonal communication.

\section{Acknowledgements}

This work was supported by 2014 Research Fund of Myongji University. I would like to thank the anonymous reviewer who gave me very useful comments and suggestions.

\section{References}

Bakeman, R., and J. Gottman. 1986. Observing Interaction: An Introduction to Sequential Analysis. Cambridge: Cambridge University Press.

Brown, P., and S. C. Levinson. 1987. Politeness: Some Universals in Language Usage. Cambridge: Cambridge University Press.

Chang, W. M., and M. Haugh. 2011. "Evaluations of Im/politeness of an Intercultural Apology." Intercultural Pragmatics 8 (3): 411-442. doi:10.1515/iprg.2011.019

Chung, Y. M. 2014. "Cheongyudaehwaeseoui hwajeseontaekkwa politeness [The selection of topics and politeness in the invitation conversation]." Journal of Japanese Language 41: 149-163.

Han, M. K. 2007. Hangugingwa ilboninui gyeongeohaengdong [Honorific Behaviors of Korean and Japanese]. Seoul: J\&C.

Han, M. K., and H. Umeda. 2009. Kankokugo no keigo nyūmon [An Instruction of Honorifics of Korean]. Tokyo: Taishūkan-shoten.

Hong, M. P. (2010) Eoneohaengdongmuhwaui hanilbigyo [A Comparative Study of Language Behavioral Culture in Korean and Japanese]. Seoul: Hanil muhwasa.

Ide, S. 1989. "Formal Forms and Discernment: Two Neglected Aspects of Universals of Linguistic Politeness." Multilingua 8: 223-248. doi:10.1515/mult.1989.8.2-3.223

Ide, S. 1997. Joseigo no sekai [The World of Female Language]. Tokyo: Meiji Shoin.

Ide, S., and M. Yoshida. 1999. "Sociolinguistics: Honorifics and Gender Differences." In The Handbook of Japanese Linguistics, ed. by N. Tsujimura, 444-478. Malden: Blackwell.

Ikeda, Y. 2000. "Hangugeowa ilboneoui hwagye [Speech levels of Korean and Japanese].” Daegu Technical College bulletin 15: 1-11.

Ikuta, S. 1983. "Speech Level Shift and Conversational Strategy." Language Sciences 5 (1): 37-53. doi:10.1016/So388-0001(83)80012-6

Ijūin, I. 2004. "Bogowasha ni yoru bamen ni ōjita speech style no tsukaiwake [Categorization of speech styles with respect to the scene of native speakers]." Shakai Gengo Kagaku 6 (2): $12-26$.

Kádár, D. Z. 2012. "Historical Chinese Politeness and Rhetoric - A Case Study of Epistolary Refusals." Journal of Politeness Research 8: 93-110. doi:10.1515/pr-2012-0006 
Kikuchi, Y. 1994. Keigo [Honorifics]. Tokyo: Kadokawa Shoten.

Kim, D. K. 2009. Keigo settōji "o · go" wo mochiita keigo no shiyō yōsō ni kansuru ichikōsatsu [A study of honorific expressions employing prefix "o · go]." Journal of the society of Japanese Language and Literature, Japanology 44: 68-84.

Kiyama, S. 2005. "Nihonjin zatsudan ni okeru hudōi - Politeness no kanten kara [Disagreement in the Japanese small talk - in respect to politeness]." Japanese Studies: Research and Education Annual Report 9: 27-48.

Kubota, T. 1990. Keigo kyōiku no shomondai [Issues in Teaching Honorifics]. Tokyo: National Language Institute.

Lee, E. M. 2008. "Danwa level kara mita nikkan no "teineido o shimesu marker no nai hatsuwa" no kinō [The function of "utterances without politeness markers"]." Journal of Japanese Language and Literature 65 (1): 179-197.

Matsumoto, Y. 1988. "Reexamination of the Universality of Face: Politeness Phenomena in Japanese." Journal of Pragmatics 12: 403-426. doi:10.1016/0378-2166(88)90003-3

Martin, S. E. 1964. Speech Levels in Japan and Korea. In Language in Culture and Society, ed. by Dell Hymes, 407-413. New York: Harper and Row.

Minami, F. 1987. Keigo [Honorifics]. Tokyo: Iwanami Shinsho.

Neustupny, J. V. 1983. "Keigokaihi no strategy nit suite [On honorific avoidance strategies]." Nihongogaku 2: 62-67.

Ogino, T. 1986. "Quantification of Politeness Based on the Usage Patterns of Honorific Expressions." International Journal of the Sociology of Language 58: 37-58.

Ogino, T. et al. 1990. "Nihongo to kankokugo no kikite ni taisuru keigo yōhō no hikaku taishō [A comparative study of addressee-honorific usage in Japanese and Korean]." Chōsengakuho 136: $1-51$.

Ogino, T. et al. 1991. "Nihongo to kankokugo no daisansha ni taisuru keigo yōhō no hikaku taishō [A comparative study of referent-honorific usage in Japanese and Korean]." Chōsengakuho 141: 1-42.

Oishi, H. 1983. Gendai keigo kenkyū [Modern Honorific Research]. Tokyo: Chikuma Shobō.

Olivieri, C. 1999. "Italia-Jin gakushūsha no nihongo ni okeru speech-level shift [Speech-level shift in the Japanese of Japanese learners]." Unpublished masters thesis, Tokyo University of Foreign Studies.

Otsuka, Y. 2004. "Terebi tōron banggumi ni okeru buntai kirikae no kōka [Effects of change in speech style in TV debate - In terms of politeness theory -]." Gifu Shōtoku gakuen daigaku kiyō Gaikokugo gakubu 43: 111-124.

Saito, J. 2010. "Subordinates' Use of Japanese Plain Forms: An Examination of Superior-subordinate Interactions in the Workplace." Journal of Pragmatics 42: 3271-3282. doi: 10.1016/j.pragma.2010.06.014

Shin, S. J. 2009. "nikkan daigakusei nokeigo ishiki to keigo kōdō no hikaku [A comparative study of honorific consciousness and honorific behavior of university students in Japanese and Korean]." Japanese Studies 28: 459-484.

Takiura, M. 2005. nihon no keigoron: politeness riron kara no saikentō [Honorific Theory in Japanese: Reexamination from the Perspective of Politeness Theory]. Tokyo: Taishūkan-shoten.

Terkourafi, M. 2005. "Beyond the Micro-level in Politeness Research." Journal of Politeness Research 1: 237-262. doi:10.1515/jplr.2005.1.2.237

Umeda, H. 1990. "Gyeongeoe gwanan hanil daejoyeogu [A contrastive study on honorifics in Korean and Japanese]." Ilbonhakji 10 (10): 95-102. 
Usami, M. 2001a. "Discourse Politeness' to iu kanten kara mita keigo shiyō no kinō - keigo shiyō no atarashii toraekata ga politeness no danwa riron ni shisa suru koto - [The function of horonific use from the perspective of discourse politeness - Implications of new analysis method of honorific use for the discourse politeness theory -]." Gogaku kenkyūjo ronshū 6: $1-29$.

Usami, M. 2001b. "Danwa no politeness: Politeness no danwa riron kōsō [Discourse politeness: Discourse theory of politeness - A Preliminary Framework -]." Danwa no politeness (Dai 7 kai kokuritsu kokugo kenkyūjo kokusai symposium hōkukusho) [Discourse Politeness](The National Language Research Institute Seventh International Symposium). Kokuritsu Kokugo Kenkyūjo [The National Language Research Institute], Tokyo: Bonjinsha, pp. 9-58.

Usami, M. 2002. Discourse Politeness in Japanese Conversation: Some Implications for a Universal Theory Politeness. Tokyo: Hituzi Syobo.

Usami, M. 2003. "Kaiteiban: kihonteki na mojika no gensoku (Basic Transcription System for Japanese: BTSJ) [A revised version: Basic transcription dystem for Japanese: BTSJ].” In Usami, M. (Chief Researcher), Tabunka kyōsei shakai ni okeru ibunka communication kyōiku no tame no kisoteki kenkyu [Core research for the education in cross-cultural communication in the multicultural society] - Heisei 13-14 Mombusho Kagaku Kenkyuhi Hojokin Kiban kenkyū (C)(2) - Kenkyū seika hōkokusho [Heisei 13-14 research report for scientific Research (C)(2) funded by Grants in Aid for scientific Research].

Usami, M. 2006. "Discourse Politeness Theory and Cross-Cultural Pragmatics." In Usage-Based Linguistic Informatics 4: Reading in Second Language Pedagogy and Second Language Acquisition in Japanese Context, ed. by A. Yoshitomi, T. Umino, and M. Negishi, 19-41. Amsterdam: John Benjamins Publishing Company. doi:10.1075/ubli.4.05usa

Usami, M., and E. M. Lee. 2003. "Shotaimen nishakan kaiwa ni okeru "teineido o shimesu marker no nai hatsuwa" no nikkan taishō kenkyū. [A comparative study of "utterances without politeness markers" In conversations between adults meeting for the first time in Japanese and Korean]." Proceedings of the conference of the Japanese Language and Literature Association of Korea, summer 2003, pp. 99-106.

Usami, M. et al. 2007. "Kihonteki na mojika no gensoku (Basic Transcription System for Japanese: BTSJ) no kankokugo eno ōyō ni tsuite [About the adaptation Basic Transcription System for Japanese: BTSJ to Korean], Danwakenkyū to nihongokyōiku no yukiteki tōgō no tame no kisoteki kenkyū to multimedia kyōzai no shisaku [Preliminary study and trial version of multimedia teaching materials for the effective integration of discourse study and Japanese education]." Heisei 15-18 Mombusho Kagaku Kenkyuhi Hojokin Kiban kenkyū (B)(2)-Kenkyū seika hōkokusho [Heisei 15-18 research report for scientific Research (B)(2) funded by Grants in Aid for scientific Research], pp. 48-82.

Yu, S. Y. 1996. "Guge cheongja daeu eomiui gyoche sayonggwa cheongja daeubeop chegye-himgwa yudaeui jeongdoseonge uihan damhwa bunseokjjeok jeopkkun [Addressee-honorific word's ending switching and the system of addressee-honorifics in Korean - Discourse analysis approach from the viewpoint of the degree of power and solidarity]." Unpublished doctoral dissertation, Korea University.

Xie, Y. 2007. "Irai kōdō no taishō kenkyū kara mita nicchū no taijin communication no tokutyō - Discourse politeness riron no kanten kara [A contrastive study of the characteristic of interpersonal communication in Japanese and Chinese requests - From the perspective of discourse politeness]." Unpublished doctoral dissertation, Tokyo University of Foreign Studies. 


\section{Appendix. Transcription conventions (Excerpt from Usami (2003))}

... Used when word endings are muddled or mumbled, or when a sentence is grammatically cut off in the middle.

? Interrogative sentence.

$<>\{<\} \quad$ When utterances occur simultaneously, both of the overlapping parts are enclosed in $<>$, After $<>,\{<\}$ is attached to the utterance that is overlapped by the other.

$<>\{>\} \quad$ Likewise, after $<>,\{>\}$ is attached to the utterance that overlaps the other.

$<>\quad$ Explanations of discourse spoken while laughing, as well as other laughter, for example, are Enclosed in $<>$, such as $<$ while laughing $>$, and $<$ both laugh $>$.

[ ] Paralinguistic and non-verbal information. Furthermore, “ $\uparrow \rightarrow \downarrow$ ” are each used to indicate rise, no change, or fall in intonation.

\section{Author's address}

Eun Mi Lee

Department of Japanese Language and Literature

Myongji University

34 Geobukgolro, Seodaemun-gu

Seoul 120-728

Korea

eunmijapan@mju.ac.kr 
